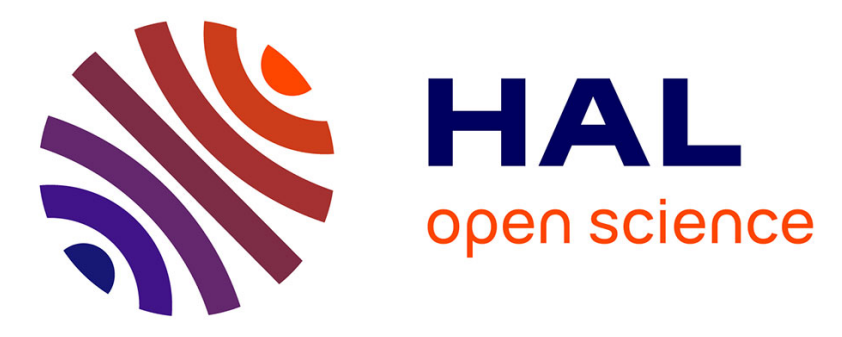

\title{
Pheromone-mediated reproductive dominance hierarchies among pseudo-clonal honeybee workers (Apis mellifera capensis)
}

Stephan Härtel, Theresa Wossler, Gert-Jan Moltzer, Robin Crewe, Robin Moritz, Peter Neumann

\section{To cite this version:}

Stephan Härtel, Theresa Wossler, Gert-Jan Moltzer, Robin Crewe, Robin Moritz, et al.. Pheromonemediated reproductive dominance hierarchies among pseudo-clonal honeybee workers (Apis mellifera capensis). Apidologie, 2011, 42 (5), pp.659-668. 10.1007/s13592-011-0066-0 . hal-01003602

\section{HAL Id: hal-01003602 https://hal.science/hal-01003602}

Submitted on 1 Jan 2011

HAL is a multi-disciplinary open access archive for the deposit and dissemination of scientific research documents, whether they are published or not. The documents may come from teaching and research institutions in France or abroad, or from public or private research centers.
L'archive ouverte pluridisciplinaire HAL, est destinée au dépôt et à la diffusion de documents scientifiques de niveau recherche, publiés ou non, émanant des établissements d'enseignement et de recherche français ou étrangers, des laboratoires publics ou privés. 


\title{
Pheromone-mediated reproductive dominance hierarchies among pseudo-clonal honeybee workers (Apis mellifera capensis)
}

\author{
Stephan Härtel ${ }^{1}$, Theresa C. Wossler ${ }^{2,3}$, Gert-Jan Moltzer ${ }^{4}$, Robin M. Crewe ${ }^{3}$, \\ Robin F. A. Moritz ${ }^{3,4}$, Peter Neumann ${ }^{5,6}$ \\ ${ }^{1}$ Department of Animal Ecology and Tropical Biology, Theodor-Boveri-Institute, Biocentre, University of \\ Würzburg, Am Hubland, 97074 Würzburg, Germany \\ ${ }^{2}$ Centre for Invasion Biology, Department of Botany and Zoology, Stellenbosch University, Private Bag X1, \\ Matieland 7602, South Africa \\ ${ }^{3}$ Department of Zoology and Entomology, University of Pretoria, Pretoria 0002, South Africa \\ ${ }^{4}$ Institut für Biologie, Molekulare Ökologie, Martin-Luther-Universität Halle-Wittenberg, Hoher Weg 4, 06099 Halle \\ (Saale), Germany \\ ${ }^{5}$ Swiss Bee Research Centre, Agroscope Liebefeld-Posieux Research Station ALP, 3033 Bern, Switzerland \\ ${ }^{6}$ Department of Zoology and Entomology, Rhodes University, Grahamstown 6140, South Africa
}

Received 23 June 2010 - Revised 16 December 2010 - Accepted 4 February 2011

\begin{abstract}
Honey bee colonies are characterised by well-developed reproductive division of labour between the queen and workers. Here, we test whether this reproductive division of labour is evident in both the socially parasitic workers that invade a colony as well as in their offspring generation. We infected six Apis mellifera scutellata host colonies with pseudo-clonal socially parasitic Cape honeybee workers (Apis mellifera capensis). We show that the first generation of socially parasitic workers can monopolize reproduction within host colonies. Of the initially invading parasites, $94.4 \%$ became reproductive pseudoqueens with activated ovaries and produced queen-like pheromones. Their offspring, however, had much lower levels of ovary activation (3.1\%), yet $89 \%$ showed fatty acid synthesis typical of the queen substance (9-oxo-2(E)-decenoic acid) biochemical pathway. However, in these second-generation workers, the last oxidation step from the precursor (9-hydroxy-2(E)-decenoic acid) to the queen substance was interrupted and appears to be required for reproductive dominance in honeybee workers. Our data show that despite the absence of genetic diversity, residual queen mandibular pheromone (QMP) variation is sufficient to establish reproductive dominance hierarchies among parasitic workers. Consequently, QMP produced by a group of workers can maintain reproductive division of labour in queenless honeybee colonies.
\end{abstract}

Cape honeybees / self-organisation / queen mandibular pheromone / response thresholds / division of labour / worker reproduction

\section{INTRODUCTION}

Eusocial insect colonies are characterised by reproductive division of labour between the queen and the workers (Wilson 1971). In the honeybee,

Corresponding author: S. Härtel, stephan.haertel@uni-wuerzburg.de Manuscript editor: Bernd Grünewald
Apis mellifera, regulation of reproduction is well understood and the reproductive dominance of the queen is mediated by chemical communication via pheromones. Worker reproduction is rare under queenright conditions and the occasional eggs produced by workers are swiftly removed by worker policing (Ratnieks and Visscher 1989). However, whenever a colony cannot replace a lost queen (hopelessly queenless condi- 
tion), worker policing is curtailed and some workers develop into pseudoqueens, by activating their ovaries, secreting queen-like pheromones and eventually producing their own offspring (Crewe and Velthuis 1980; Ruttner and Hesse 1981; Hepburn 1992; Wossler 2002; Velthuis et al. 1990). The chances of becoming a pseudoqueen are nevertheless not equal among workers. The queen mates with 10-20 drones resulting in multiple worker subfamilies in the colony (Estoup et al. 1994). Members of some subfamilies have a higher probability than others of developing as pseudoqueens (Moritz et al. 1996; Martin et al. 2004; Härtel et al. 2006a; Makert et al. 2006), or queens (Moritz et al. 2005b), suggesting high genetic variance for reproductive dominance among worker subfamilies. Aworker's position in the reproductive dominance hierarchy is largely mediated by her mandibular secretions, and the more queen-like the secretions, the higher is the worker's position (Moritz et al. 2000, 2004; Simon et al. 2005; Dietemann et al. 2006, 2007). Moreover, it has been shown that the expression of queen-like mandibular pheromones by workers has a strong genetic component (Moritz and Hillesheim 1985; Lattorff et al. 2005, 2007).

The fatty acids of the queen mandibular gland pheromone (QMP) cause changes in both behaviour (releaser function) and physiology (primer function) of workers (Slessor et al. 1988; Winston et al. 1989; Naumann et al. 1991; Winston and Slessor 1992; Keeling et al. 2003; Hoover et al. 2003; Slessor et al. 2005). The major component of QMP is the so-called "queen substance" (9-keto-2-(E)-decenoic acid, 9-ODA) (Barbier and Lederer 1960; Butler et al. 1961; Pain $1961)$ whereas 10-hydroxy-2- $(E)$-decenoic acid (10-HDA) and 10-HDAA (10-hydroxydecanoic acid) are the major components of the worker mandibular pheromone. The two caste specific biochemical pathways of the mandibular gland pheromones are derived from the same $\omega$ hydroxy-18-carbon fatty acids by chain reduction towards ten carbons (Plettner et al. 1996, 1998).

Pseudoqueens live for 3 to 5 months (Velthuis et al. 1990) approximately three times longer than non-reproductive workers. Pseudoqueens produce queen-like mandibular gland pheromones with 9-
ODA dominating the secretion (Hemmling et al. 1979; Crewe and Velthuis 1980; Plettner et al. 1993). A pseudoqueen will prevent other workers from becoming pseudoqueens with its queen-like pheromonal signal, but it has attained pseudoqueen status, it is not affected by the queen-like signals of others (Simon et al. 2005; Hoover et al. 2003; Dietemann et al. 2007).

While there is clear evidence for genotypic variance in worker reproduction under queenless conditions, very little is known about pheromonal reproductive competition between workers with identical genotypes. Genetic variance among workers normally facilitates differential QMP production. Workers genetically predisposed to become pseudoqueens, through the production of QMP, therefore will be dominant over others. In such a scenario, Moritz and Crewe (2005) suggested a mechanism based on self-regulatory interactions of queen pheromone production among the workers in queenless colonies resulting in a reproductive division of labour between pseudoqueens and non-reproductive workers. This mechanism would be adaptive if it increases colony-level reproductive success. To test the impact of queen-like pheromone production (Moritz and Crewe 2005), we need to eliminate genetic variation from the analysis. Consequently, we take advantage of the Cape honeybee, Apis mellifera capensis, in which laying workers produce pseudo-clonal offspring via thelytokous parthenogenesis (Verma and Ruttner 1983; Pearcy et al. 2006). In 1990, a single pseudoclonal lineage of socially parasitic workers of $A$. mellifera capensis was established that invades conspecific Apis mellifera scutellata populations in extensive regions of northern South Africa (Baudry et al. 2004; Härtel et al. 2006b; Neumann et al. 2011). This lineage has probably been selected for its ability to produce queenlike mandibular gland secretions (Dietemann et al. 2007) and to become reproductive despite the presence of the A. mellifera scutellata host queen (Dietemann et al. 2006). We utilised this pseudo-clone in order to study reproductive dominance hierarchies among workers in the absence of genetic variance. We determined 
QMP-meditated dominance hierarchies between pseudo-clonal $A$. mellifera capensis workers and their offspring during the course of invading A. mellifera scutellata host colonies. Although the effect of QMP on worker reproduction has widely been studied, data on the pheromonal regulation of worker exocrine secretions are scanty (Katzav-Gozansky et al. 2006). In this study, we use the parasitic pseudo-clone worker lineage to investigate the development of pseudoqueens and dominance hierarchies in genetically uniform groups.

\section{MATERIALS AND METHODS}

\subsection{Sampling of the experimental worker groups}

Unrelated queenright test colonies of $A$. mellifera scutellata $(n=6)$ were obtained from their native range (Ixopo, KwaZulu Natal, South Africa, Hepburn and Radloff 1998) and placed $1 \mathrm{~m}$ apart in a test apiary in Grahamstown (Eastern Cape). Offspring of the ubiquitous socially parasitic $A$. mellifera capensis pseudoclone ( $n=10$ colonies) (Baudry et al. 2004; Härtel et al. 2006b; Neumann et al. 2011) were obtained from $A$. mellifera scutellata host colonies $(n=6)$ which were in late stages of infestation (reviewed by Neumann and Hepburn 2002; Härtel et al. 2006b) from Pretoria (Gauteng). The test colonies were fed ad libidum with a mixture of honey, pollen and sugar water.

\subsection{Experimental set-up}

Sealed A. mellifera capensis parasitic worker brood and the A. mellifera scutellata worker brood frames were incubated at $35^{\circ} \mathrm{C}$ until adult emergence. The emerging A. mellifera capensis parasitic workers $(N=700)$ and $A$. mellifera scutellata $(N=300)$ were individually marked and introduced into the six test $A$. mellifera scutellata colonies. In order to secure a high rate of acceptance, we sprayed the test workers with a honey sugar/water solution just before introducing them. All host colonies were successfully infested by the social parasites. One week after the introduction, 150 of the 700 introduced A. mellifera capensis parasites were still present in the host colonies. Over a period of 6 weeks, the colonies were monitored for the number of remaining labelled test workers. Parasitic worker samples were taken weekly with $12 \pm 7$ workers collected. The $A$. mellifera scutellata host workers were sampled at $2(N=11$ workers $)$ and 4 weeks $(N=11$ workers) after their introduction.

After 4 weeks, brood frames containing offspring of the introduced parasitic workers were removed from the now queenless $A$. mellifera scutellata test colonies ( $n=$ 3; Härtel et al. 2006b) and incubated until adult emergence. The newly emerged offspring were marked and reintroduced into their mother colonies. Again the offspring workers were collected on a weekly basis for up to 6 weeks. In both generations of parasites (initially introduced workers $N=35$, offspring $N=11$ ), their possession of the ubiquitous parasitic worker genotype was confirmed via DNA microsatellite genotyping (Baudry et al. 2004; Härtel et al. 2006b, Neumann et al. 2011) using six polymorphic loci (A14, A28, A35, A88, A113 and B124).

\subsection{Ovarian activation}

In order to analyse the reproductive status of the sampled workers, the abdomens were dissected and the developmental stage of the ovaries was assessed using standard criteria (Velthuis 1970): $\mathrm{I}=$ no activation, II=round or bean-shaped eggs visible (early stage of activation) and III=fully developed ovarioles with mature eggs.

\subsection{Mandibular gland pheromone development}

The sampled workers were decapitated and their heads were extracted in $200 \mu \mathrm{L}$ dichloromethane (DCM) for spectroscopy (Merck, Uvasol). The extracts were evaporated just to dryness under a stream of $\mathrm{N}_{2}$ and the acids in the extracts were derivitised with $20 \mu \mathrm{L}$ bis-(trimethylsilyl) triflouroacetamide (Merck) and quantified according to the method of Gehrke and Leimer (1971). Twenty microlitres of internal standard (octanoic acid and tetradecane in DCM, Sigma) was also added to the sample. One microlitre of this solution was analysed on a Hewlett-Packard 5,890 gas chromatograph fitted with a split-splitless injector, a flame ionization detector and a cross-linked methyl silicone HP-1 
column $(25 \mathrm{~m} \times 0.32 \mathrm{~mm} \times 0.52 \mu \mathrm{m})$ which was temperature programmed at $60^{\circ} \mathrm{C}(1 \mathrm{~min}), 50^{\circ} \mathrm{C} / \mathrm{min}$ to $100^{\circ} \mathrm{C}$ and $3^{\circ} \mathrm{C} / \mathrm{min}$ to $220^{\circ} \mathrm{C}(10 \mathrm{~min})$. The injection port was set at $230^{\circ} \mathrm{C}$ while the detector temperature was $280^{\circ} \mathrm{C}$. The mandibular gland compounds were identified by comparing their mass spectra with those of pure compounds accessed via the Wiley database or by comparisons of the retention times with authentic standard compounds using HP Chemstation software. The amounts of the individual produced mandibular gland components (9-ODA, 9HDA, 10-HDA and 10-HDAA) were quantified per sampled worker. A standard solution containing the 9-ODA and 10-hydroxy-(E)-decanoic acid (10-HDA) was run daily to ensure that relative mass ratios were within the limit of variability found in the series of standard runs (Crewe and Moritz 1989). We determined the bias towards the queen substance or worker substance pathway by measuring the ratio of queen-like substances (9-ODA and 9-HDA) and worker-like substances (10-HDA and 10-HDAA) in relation to the total analysed mandibular gland components; total mandibular components $\mathrm{TMC}=$ $(9-\mathrm{ODA}+9-\mathrm{HDA}+10-\mathrm{HDA}+10-\mathrm{HDAA})$. The pheromone ratios data were arcsine transformed and analysed with Statistica ${ }^{\circ}$.

\section{RESULTS}

We did not find a significant difference in the age of the sampled socially parasitic parental and offspring workers (parental, 25.8 \pm 11.2 days, $n=72$; offspring, $28.2 \pm 10.2$ days, $n=32$ ).

\subsection{DNA genotyping}

The DNA microsatellite analysis revealed that of all tested A. mellifera capensis workers (both the initially introduced workers $(n=35)$ and their first offspring $(n=11))$ belonged to the ubiquitous distributed pseudo-clonal genotype (Baudry et al. 2004; Härtel et al. 2006b; Neumann et al. 2011).

\subsection{Pheromonal development}

The 9-ODA production of the first generation of introduced A. mellifera capensis workers ( $n=$ $72 ; 85.5 \pm 15.4 \%$ SD) was significantly higher (Mann-Whitney $U$ test, $U=68.5$ and $P<0.05$ ) than that of their offspring $(n=32 ; 29.1 \pm 21.3 \%$; Figure 1). The parasitic offspring produced more 9-HDA $(60.0 \pm 22.4 \% ; \quad U=139$ and $P<$ $0.05)$ than the parental parasites $(13.6 \pm 1.6 \%$; Figure 1). The parasitic offspring $(89.1 \pm 23.6 \%)$ produce significantly less queen-like mandibular substances (9-ODA+9-HDA; Figure 1; $U=$ 691 and $P>0.001)$ than the parental generation $(97.6 \pm 8.2 \%)$.

The parasitic offspring however, produced significantly more worker-like substances in their mandibular glands compared with the initially introduced parasitic workers $(10.9 \pm$ $23.9 \%$ and $2.4 \pm 8.2 \% ; U=691$ and $P<0.001)$. In contrast, the $A$. mellifera scutellata host workers produced only traces of 9-ODA ( $n=$ $18 ; 6.1 \% \pm 20.7)$. The worker-like alipathic mandibular gland acids (10-HDA+10-HDAA/

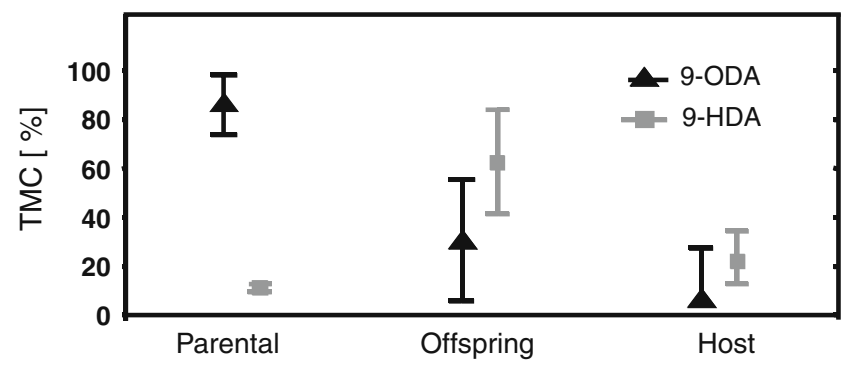

Figure 1. Proportions (means \pm SD) of queen mandibular gland components (9-ODA and 9-HDA) from the initial introduced A. mellifera capensis parental socially parasitic workers, their pseudo-clonal offspring and the host workers in the total mandibular aliphatic acid mixture (TMC=9-ODA+9-HDA+10-HDA+10-HDAA) are shown. 
9-ODA + 9-HDA + 10-HDA + 10-HDAA) dominated the mandibular gland secretions of $A$. mellifera scutellata workers $73.9 \pm 21.8 \%$.

\subsection{Ovarian activation}

The first generation of parasitic A. mellifera capensis workers $(N=72)$ showed significantly more activated ovaries compared with their offspring and the A. mellifera scutellata host workers (Kruskal-Wallis ANOVA, $d f=2, H=$ 98.49 and $P<0.001)$. While $94.4 \%$ of the initially introduced parasites had fully activated ovaries (stage III), only a single worker of the parasitic offspring had fully activated ovaries. All dissected A. mellifera scutellata host workers $(N=22)$ were classified as ovarial stage I (Figure 2).

\subsection{Correlation between 9-ODA and ovarian activation}

The proportion of 9-ODA in the total pheromone blend (9-ODA/9-ODA+9-HDA+ 10-HDA+10-HDAA) showed a significant correlation with the ovarian activation in $A$. mellifera capensis parasitic workers $(n=104, R=0.799$ and $P<0.01$; Figure 3 ). There was no significant difference in the proportion of 9-ODA present in the pheromone blend of individuals with stage I and II ovarian activation ( $n=35$ and $P>0.05$; Figure 3).

\section{DISCUSSION}

The first generation of introduced parasitic workers monopolized reproduction in the invaded colonies. However, only $3.1 \%$ of the parasitic offspring workers, with identical genotypes to those of the introduced parasitic workers, and none of the A. mellifera scutellata host workers developed into reproductive pseudoqueens. The extreme differences in the phenotypes of pseudo-clone workers show that genetic variance is not essential to initiate the self-regulatory process of reproduction and sterility among workers. Our study also shows that the variation in mandibular gland pheromone concentration is sufficient to regulate the process of separating reproductive from subordinate workers. This regulatory mechanism contributes to the residual colony fitness after queen loss due to the establishment of reproductive division of labour between pseudoqueens and their offspring workers.

The first generation of $A$. mellifera capensis workers activated their ovaries in the presence of a laying A. mellifera scutellata host queen, while the host workers did not. Obviously, the response threshold to the queen's pheromones is

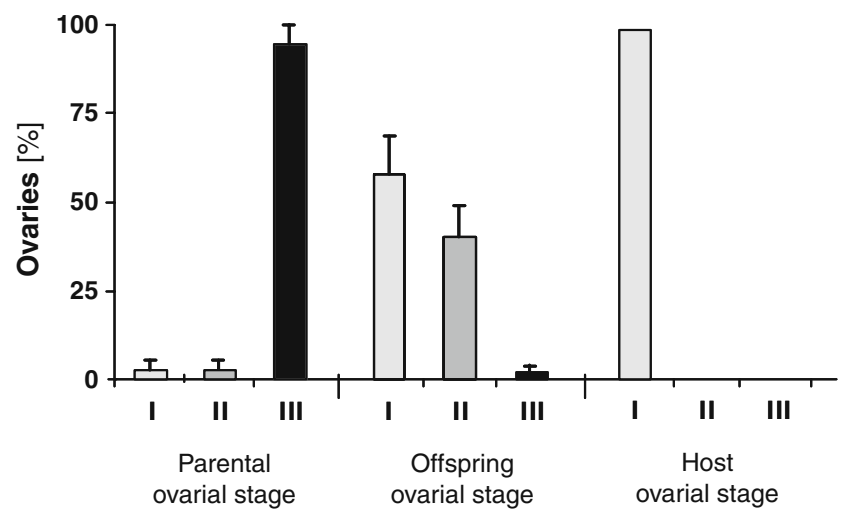

Figure 2. The stages of ovarian activation (means $\pm \mathrm{SE}$ ) of the parental generation of socially parasitic workers ( $n=72$ and $n=6$ A. mellifera scutellata host colonies), their pseudo-clonal offspring ( $n=32$ and $n=3$ host colonies) and A. mellifera scutellata host workers ( $n=22$ and $n=3$ host colonies) are shown. 


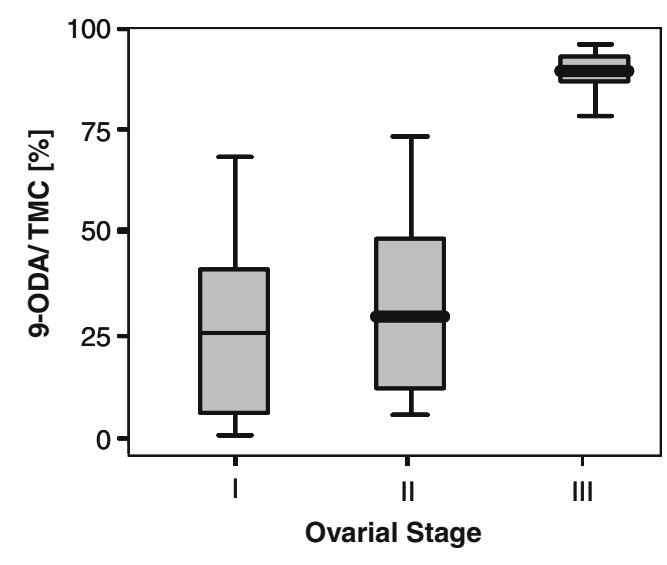

Figure 3. Box plot of a Spearman's rank correlation between ovarian activation and the proportion of 9ODA in the total mandibular aliphatic acid mixture $(\mathrm{TMC}=9-\mathrm{ODA}+9-\mathrm{HDA}+10-\mathrm{HDA}+10-\mathrm{HDAA})$ of socially parasitic $A$. mellifera capensis workers ( $n=$ $104)$ in A. mellifera scutellata host colonies $(n=6)$ are shown. Quartile, whisker caps and median lines are given.

different in the parasite and host worker groups with the parasitic workers not being affected by the QMP of the host queen. Variance for suppression thresholds of individual workers has been repeatedly reported (Oldroyd et al. 1994; Pankiw et al. 2000; Hoover et al. 2005; Dor et al. 2005, Dietemann et al. 2006). In this study, the higher threshold for the queen pheromone in $A$. mellifera capensis workers compared with the A. mellifera scutellata workers indicate genetic differences between the two subspecies for this trait. This difference is fundamental and predisposes Cape honeybee workers to act as social parasites in A. mellifera scutellata colonies with well known devastating consequences for beekeeping (Allsopp and Crewe 1993; Greeff 1997; Neumann and Hepburn 2002; Moritz et al. 2005a; Dietemann et al. 2006). The queen-like pheromone secretion of the first generation of $A$. mellifera capensis social parasites (Figure 1) is consistent with the laboratory results obtained by Dietemann et al. (2006) who showed that pseudo-clone workers produced queen-like mandibular gland secretions even in the presence of $A$. mellifera scutellata mandibular queen signals. In addition, also under field conditions our data clearly show that the ovary activation in pseudo-clone workers is not suppressed by the host queen.

The very different fate of first generation social parasites (developing into pseudoqueens) and their offspring (remaining sterile) provides further insight into the self-regulatory process of queen pheromone development through worker-worker interactions (Moritz and Crewe 2005). Since QMP inhibits ovary activation and QMP production in other workers (Moritz et al. 2000; Dietemann et al. 2007), these hierarchies are most likely established due to changing queen pheromone levels in the colony during the course of invasion. In the initial phase, the pheromone signal of the resident $A$. mellifera scutellata queens is not sufficient to regulate the reproductive development of introduced parasitic A. mellifera capensis workers. Consequently, parasitic pseudoqueens can develop rapidly after invasion. When established parasitic pseudoqueens interact with the host queen through lethal fights (Moritz et al. 2003) or through pheromonal competition with the resident queen (Dietemann et al. 2006), they are capable of taking over their host colonies. Our data explain observations of previous studies in that only a small number of socially parasitic workers reach reproductive development within infected host colonies (Martin et al. 2002; Swart 2003). We show that small groups of invading parasitic workers or the first offspring of a single invading worker can monopolize worker reproduction in the host colony, thereby establishing reproductive dominance hierarchies among pseudo-clone honeybee workers (Figures 1, 2 and 3 ).

Although reproduction is suppressed in the parasitic offspring, they rarely take part in worker tasks such as foraging (Martin et al. 2002). Since genotypic variance is an important factor in the maintenance of a honeybee colony (recently reviewed by Oldroyd and Fewell 2007), it is not surprising that even non-reproductive $A$. mellifera capensis workers of this particular socially parasitic pseudo-clone do not take over all tasks to the same degree as host workers do. 
This appears to be one of the main reasons for the eventual death of the host colony subsequent to the initial invasions (Neumann and Hepburn 2002; Härtel et al. 2006b).

It could be demonstrated by Lattorff et al. (2007) that queen-like mandibular secretions of honeybee workers are strongly linked to the Th locus. Indeed, about $95 \%$ of the pseudo-clonal parasitic workers follow the biochemical pathway towards the queen substance (Figure 1). However, the offspring generation could not finalize the biochemical pathway to the end product 9-ODA, indicating the influence of the established reproductive workers of the parental generation. Non-reproductive workers show only low proportions of 9-ODA in their mandibular gland secretions while their ovaries are not fully developed (Figure 2), resulting in a strong correlation between 9-ODA production and ovary activation (Figure 3 ). Our findings therefore point to 9-ODA as a fertility signal in socially parasitic honeybee workers. This fertility signal could open a route to the social pathway of worker reproduction (Schäfer et al. 2006).

Workers that track the biochemical pathway of queen substance production but do not show complete ovary activation are most likely able to infect new host colonies. In these workers, the queen-like pheromone production is arrested at the 9-HDA stage but may be predisposed to reproductive dominance. Traits for reproductive dominance of workers are pleiotropically linked to the thelytoky locus (Lattorff et al. 2007). Individuals homozygous for the Th allele show both worker ovary activation and queen-like mandibular secretions. Under the condition of invading a new host colony a reproductive head start is plausible because these pseudoclone social parasites that have been selected for reproductive traits (Dietemann et al. 2007; Neumann et al. 2011) can easily reach reproductive dominance in the new host colony.

Workers producing queen-like mandibular secretions have been shown to suppress mandibular gland signal development in neighbouring workers during laboratory studies (e.g. Moritz et al. 2000; Dietemann et al. 2007). However, our study is the first to suggest the relevance of this phenomenon in the field. Our data highlight that parasitic honeybee workers under queenless conditions use queen-like mandibular pheromones to establish a higher rank in the reproductive dominance hierarchies of the infected colony. These hierarchies are most likely the result of self-regulatory mechanisms of worker-worker interactions through differential response thresholds to 9-ODA concentrations controlled by at least two feedback loops (Moritz and Crewe 2005). The pseudo-clone parasitic offspring utilise the biochemical pathway leading to the queen substance but there is a second regulatory point that inhibits the final oxidation step to the actual queen substance 9-ODA. As a consequence, the pseudo-clone worker offspring remain sterile and reproductive division of labour appears to be an inevitable feature of queenless honeybee workers even in the absence of genetic variance, which normally facilitates this process.

In conclusion, our findings support the significant role of mandibular queen pheromone production in the observed reproductive division of labour of queenless honeybee colonies. The within-colony dynamics of pheromone levels are likely to be the central proximate mechanism for regulating which individuals will be reproductive, whereas the genetic differences among the workers predispose them to become reproductive or remain sterile. At the ultimate level, it is the local intracolony environment to which the individual is exposed to that determines whether it will develop into a pseudoqueen or not.

\section{ACKNOWLEDGEMENTS}

We are grateful to Petra Leibe for technical assistance. Financial support was granted by an Emmy Noether fellowship of the DFG (PN), a postdoctoral fellowship of the University of Pretoria (TCW), the VW foundation (RFAM and RMC) and the National Research Foundation of South Africa (RMC). We thank H. Randall Hepburn and an 
anonymous referee for helpful comments on an earlier version of the manuscript.

Orientation phéromonale de la hiérarchie de dominance reproductive chez les abeilles ouvrières pseudo-clonales (A. mellifera capensis).

abeille du Cap / phéromone mandibulaire / reine / seuil de réponse / reproduction des ouvrières / division du travail

\section{Pheromon vermittelte reproduktive Dominanz- hierarchien zwischen pseudo-klonalen Arbeiterin- nen der Kaphonigbiene.}

Kaphonigbiene / Selbstorganisation / Königinnen Mandibelpheromon / Resonanz-Schwellenwert / Reproduktive Arbeitsteilung / Arbeiterinnen Reproduktion

\section{REFERENCES}

Allsopp, M.H., Crewe, R.M. (1993) The Cape honeybee as a Trojan horse rather than the hordes of Jenghiz Khan. Am. Bee J. 133, 121-123

Barbier, J., Lederer, E. (1960) Structure chimique de la substance royale de la reine d'abeille (Apis mellifera L.). C. R. Acad. Sci., Ser. 3 Sci Vie. 251, 1131-1135

Baudry, E., Kryger, P., Allsopp, M.H., Koeniger, N., Vautrin, D., Mougel, F., Cornuet, J.-M., Solignac, M. (2004) Whole-genome scan in thelytokous-laying workers of the Cape honeybee (A. m. capensis): central fusion, reduced recombination rates and centromere mapping using half tetrad analysis. Genetics 167, 243-252

Butler, C.G., Callow, R.K., Johnston, N.C. (1961) The isolation and synthesis of queen substance, 9oxodec-trans-2-enoic acid, a honeybee pheromone. Proc. R. Soc. Lond., B Biol Sci. 155, 417-432

Crewe, R.M., Moritz, R.F.A. (1989) Variation in the components of head extracts of workers and queens of Apis mellifera intermissa Buttel-Reepen. Z. Naturforsch. 44, 590-596

Crewe, R.M., Velthuis, H.H.M. (1980) False queens: a consequence of mandibular gland signals in worker bees. Naturwissenschaften 65, 467-469

Dietemann, V., Pflugfelder, J., Härtel, S., Neumann, P., Crewe, R.M. (2006) Social parasitism by honeybee workers (Apis mellifera capensis Esch.): evidence for pheromonal resistance to host queens signals. Behav. Ecol. Sociobiol. 60, 785-793

Dietemann, V., Neumann, P., Härtel, S., Pirk, C.W.W., Crewe, R.M. (2007) Pheromonal dominance and the selection of a socially parasitic honeybee worker lineage (Apis mellifera capensis Esch.). J. Evol. Biol. 20, 997-1007

Dor, R., Katzav-Gozansky, T., Hefetz, A. (2005) Dufour's gland pheromone as a reliable fertility signal among honeybee (Apis mellifera) workers. Behav. Ecol. Sociobiol. 58, 270-276

Estoup, A., Solignac, M., Cornuet, J. (1994) Precise assessment of the number of patrilines and of genetic relatedness in honeybee colonies. Proc. R. Soc. Lond., B Biol Sci. 258, 1-7

Gehrke, C.W., Leimer, K. (1971) Trimethylsilylation of amino acids. Derivatization and chromatography. J. Chromatography 57, 219-238

Greeff, J.M. (1997) The Cape honeybee and her way north: an evolutionary perspective. S. Afr. J. Sci. 93, 306-308

Härtel, S., Neumann, P., Raasen, F.S., Moritz, R.F.A., Hepburn, H.R. (2006a) Social parasitism by Cape honeybee workers in colonies of their own subspecies (Apis mellifera capensis Esch.). Insect. Soc. 53, 183-193

Härtel, S., Neumann, P., Kryger, P., von der Heide, C., Moltzer, G.-J., Crewe, R.M., van Praagh, J.P., Moritz, R.F.A. (2006b) Infestation levels of Apis mellifera scutellata swarms by socially parasitic Cape honeybee workers (Apis mellifera capensis Esch.). Apidologie 37, 462-470

Hemmling, C., Koeniger, N., Ruttner, F. (1979) Quantitative Bestimmung der 9-Oxodecensäure im Lebenszyklus der Kaphonigbiene (Apis mellifera capensis Escholtz). Apidologie 10, 227-240

Hepburn, H.R. (1992) Pheromonal and ovarial development covary in Cape worker honeybees (Apis mellifera capensis). Naturwissenschaften 79, 523-524

Hepburn, H.R., Radloff, S.E. (1998) Honeybees of Africa. Springer, New York

Hoover, S.E.R., Keeling, C.I., Winston, M.L., Slessor, K. N. (2003) The effect of queen pheromones on worker honey bee ovary development. Naturwissenschaften 90, 477-480

Hoover, S.E.R., Keeling, C.I., Winston, M.L., Oldroyd, B.P. (2005) Retinue attraction and ovary activation: responses of wild type and anarchistic honey bees (Apis mellifera) to queen and brood pheromones. Behav. Ecol. Sociobiol. 59, 278-284

Katzav-Gozansky, T., Boulay, R., Soroker, V., Hefetz, A. (2006) Queen pheromones affecting the production of queen-like secretion in workers. J. Comp. Physiol. A 192, 737-742

Keeling, C.I., Slessor, K.N., Higo, H.A., Winston, M.L. (2003) New components of the honey bee (Apis mellifera L.) queen retinue pheromone. PNAS 100, 4486-4491

Lattorff, H.M.G., Moritz, R.F.A., Fuchs, S. (2005) A single locus determines thelytokous parthenogenesis of laying honeybee workers (Apis mellifera capensis). Heredity 94, 533-537 
Lattorff, H.M.G., Moritz, R.F.A., Crewe, R.M., Solignac, M. (2007) Control of reproductive dominance by the thelytoky gene in honeybees. Biol. Letters 3, 292295

Makert, G.R., Paxton, R.J., Hartfelder, K. (2006) Ovariole number - a predictor of differential reproductive success among worker subfamilies in queenless honeybee (Apis mellifera L.) colonies. Behav. Ecol. Sociobiol. 60, 815-825

Martin, S.J., Wossler, T.C., Kryger, P. (2002) Usurpation of African Apis mellifera scutellata colonies by parasitic Apis mellifera capensis workers. Apidologie 33, 215232

Martin, C.G., Oldroyd, B.P., Beekman, M. (2004) Differential reproductive success among subfamilies in queenless honeybee (Apis mellifera L.) colonies. Behav. Ecol. Sociobiol. 56, 42-49

Moritz, R.F.A., Crewe, R.M. (2005) The interplay of intracolonial genotypic variance and self-organisation of dominance hierarchies in honeybees. In: Hemelrijk, C.K. (ed.) Self-Organisation and Evolution of Social Behaviour, pp. 36-49. Cambridge University Press, Cambridge

Moritz, R.F.A., Hillesheim, E. (1985) Inheritance of dominance in honeybees (Apis mellifera capensis). Behav. Ecol. Sociobiol. 17, 87-89

Moritz, R.F.A., Kryger, P., Allsopp, M.H. (1996) Competition for royalty in bees. Nature $\mathbf{3 8 4}, 31$

Moritz, R.F.A., Simon, U.E., Crewe, R.M. (2000) Pheromonal contest between honeybee workers. Naturwissenschaften 87, 395-397

Moritz, R.F.A., Pflugfelder, J., Crewe, R.M. (2003) Lethal fighting between honeybee queens and parasitic workers (Apis mellifera). Naturwissenschaften 90, 378-381

Moritz, R.F.A., Lattorff, H.M.G., Crewe, R.M. (2004) Honeybee workers (Apis mellifera capensis) compete for producing queen-like pheromone signals. Proc. R. Soc. Lond 271(Suppl.), S98-S100

Moritz, R.F.A., Härtel, S., Neumann, P. (2005a) Global invasions of the western honeybee (Apis mellifera L.) and the consequences for biodiversity. Écoscience 12, 289-301

Moritz, R.F.A., Lattorff, H.M.G., Neumann, P., Kraus, F. B., Radloff, S.E., Hepburn, H.R. (2005b) Rare royal families in honeybees, Apis mellifera. Naturwissenschaften 92, 488-491

Naumann, K., Winston, M.L., Slessor, K.N., Prestwich, G.D., Webster, F.X. (1991) Production and transmission of honey bee queen (Apis mellifera L.) mandibular gland pheromone. Behav. Ecol. Sociobiol. 29, 321-332

Neumann, P., Hepburn, H.R. (2002) Behavioural basis for social parasitism of Cape honeybees (Apis mellifera capensis Esch.). Apidologie 33, 165-192

Neumann, P., Härtel, S., Kryger, P., Crewe, R.M., Moritz, R.F. A. (2011) Reproductive division of labor and thelytoky result in sympatric barriers to gene flow in honeybees (Apis mellifera L.). J. Evol. Biol. 24, 286-294

Oldroyd, B.P., Fewell, J.H. (2007) Genetic diversity promotes homeostasis in insect colonies. Trends Ecol. Evol. 22, 408-413

Oldroyd, B.P., Smolenski, A.J., Cornuet, J.-M., Crozier, R.H. (1994) Anarchy in the beehive: a failure of worker policing in Apis mellifera. Nature 371, 479

Pain, J. (1961) Sur la phéromone des reines d'abeilles et ses effets physiologiques. Ann. Abeille. 4, 73-152

Pankiw, T., Winston, M.L., Fondrk, K.M., Slessor, K.N. (2000) Selection on worker honeybee responses to queen pheromone (Apis mellifera L.). Naturwissenschaften 87, 487-490

Pearcy, M., Hardy, O., Aron, S. (2006) Thelytokous parthenogenesis and its consequences on inbreeding in an ant. Heredity 96, 377-382

Plettner, E., Slessor, K.N., Winston, M.L., Robinson, G. E., Page, R.E. (1993) Mandibular gland components and ovarian development as measures of caste differentiation in the honey bee (Apis mellifera L.). J. Insect Physiol 39, 235-240

Plettner, E., Slessor, K.N., Winston, M.L., Oliver, J.E. (1996) Caste-selective pheromone biosynthesis in honeybees. Science 271, 1851-1853

Plettner, E., Slessor, K.N., Winston, M.L. (1998) Biosynthesis of mandibular acids in honey bees (Apis mellifera). De novo synthesis, route of fatty acid hydroxylation and caste-selective b-oxidation. Insect Biochem. and Mol. Biol. 28, 31-42

Ratnieks, F.L.W., Visscher, P.K. (1989) Worker policing in the honeybee. Nature 342, 796-797

Ruttner, F., Hesse, B. (1981) Rassenspezifische Unterschiede in Ovarentwicklung und Eiablage von weisellosen Arbeiterinnen der Honigbiene Apis mellifera L. Apidologie 12, 159-183

Schäfer, M.O., Dietemann, V., Pirk, C.W.W., Neumann, P., Crewe, R.M., Hepburn, H.R., Tautz, J., Crailsheim, K. (2006) Individual versus social pathway to honeybee worker reproduction (Apis mellifera): pollen or jelly as protein source for oogenesis? J. Comp. Physiol. A 192, 761-768

Simon, U., Moritz, R.F.A., Crewe, R.M. (2005) Reproductive dominance among honeybee workers in experimental groups of Apis mellifera capensis. Apidologie 36, 413-419

Slessor, K.N., Foster, L.J., Winston, M.L. (1988) Royal flavours: honey bee queen pheromones. In: Van der Meer, R.K., Breed, M.D., Winston, M.L., Espelie, K.E. (eds.) Pheromone Communication in Social Insects, pp. 331-343. Westview, Boulder

Slessor, K.N., Winston, M.L., Le Conte, Y. (2005) Pheromone Communication in the Honeybee (Apis mellifera L.). J. Chem. Ecol. 31, 2731-2745

Swart J.D. (2003) The occurrence of Nosema apis (Zander), Acarapis woodi (Rennie), and the Cape 
honeybee problem in the summer rainfall region of South Africa. M.Sc. thesis, Rhodes University, Grahamstown, South Africa, pp 67

Velthuis, H.H.W. (1970) Ovarian development in Apis mellifera worker bees. Entomol. Exp. Appl. 13, 377-394

Velthuis, H.H.W., Ruttner, F., Crewe, R.M. (1990) Differentiation in reproductive physiology and behaviour during the development of laying worker honeybees. In: Engels, W. (ed.) Social Insects, pp. 231-243. Springer, Berlin

Verma, S., Ruttner, F. (1983) Cytological analysis of the thelytokous parthenogenesis in the Cape honeybee (Apis mellifera capensis Escholtz). Apidologie 14, 41-57
Wilson, E.O. (1971) The Insect Societies. Harvard University Press, Cambridge

Winston, M.L., Slessor, K.N. (1992) The essence of royalty: honey bee queen pheromone. Am. Sci. 80, 374-385

Winston, M.L., Slessor, K.N., Willis, L.G., Naumann, K., Higo, H.A., Wyborn, M.H., Kaminski, L.A. (1989) The influence of queen mandibular pheromones on worker attraction to swarm clusters and inhibition of queen rearing in the honey bee (Apis mellifera $\mathrm{L}$.). Insect. Soc. 36, 15-27

Wossler, T.C. (2002) Pheromone mimicry by Apis mellifera capensis social parasites leads to reproductive anarchy in host A. m. scutellata colonies. Apidologie 33, 139-163 